\title{
Cost Share Programs for Florida's Agricultural Producers and Landowners ${ }^{1}$
}

Rao Mylavarapu, Kelly Hines and Alyssa Dodd ${ }^{2}$

\section{Introduction}

Several U.S. Department of Agriculture (USDA) sponsored programs encourage and reward agricultural producers and landowners practicing environmental stewardship. Authorized by the federal Farm Bill and administered by the USDA-Natural Resources Conservation Service (NRCS), these programs provide technical and financial assistance to eligible producers and landowners who voluntarily implement practices to protect soil, water, air, wildlife habitats, and related natural resources. Conservation funding in the 2008 Farm Bill represents about $\$ 25$ billion of the almost $\$ 300$ billion in new spending authorized by the bill over the next five years (beginning October 2009).

However, it is important to remember that while the 2008 Farm Bill provides some mandatory funding, many of the programs require annual appropriations from Congress (U.S. House Committee on Agriculture, 2008). The 2008 Farm Bill increases total spending on conservation programs by almost $\$ 8$ billion.
This fact sheet describes the Environmental Quality Incentives Program (EQIP), Wetlands Reserve Program (WRP), Grassland Reserve Program (GRP), Wildlife Habitats Incentive Program (WHIP), and the Conservation Security Program (CRP). These programs may be of high interest to farmers, ranchers, land owners, agricultural consultants, local decision-makers and extension agents (USDA-NRCS, 2002).

\section{Environmental Quality Incentive Program (EQIP)}

The EQIP provides technical and financial assistance to agricultural producers and ranchers who voluntarily install/implement structural and management practices on eligible agricultural land to protect soil, water, air quality and/or wildlife habitat. The program promotes agricultural production and environmental quality (USDA-NRCS, 2004). In 2006 alone, this program enrolled 51.5 million acres and awarded approximately $\$ 1$ billion worth of technical and financial assistance. For established farmers, conservation measures may be cost-shared up to $75 \%$. In the case of beginning farmers or those with limited

1. This document is SL264, one of a series of the Soil and Water Science Department, Florida Cooperative Extension Service, Institute of Food and Agricultural Sciences, University of Florida. Original publication date October 2008. Visit the EDIS Web Site at http://edis.ifas.ufl.edu.

2. Rao Mylavarapu, associate professor, nutrient management specialist, Department of Soil and Water Science; Kelly Hines, chemist, Nutrient Management Program, Department of Soil and Water Science; and Alyssa Dodd, environmental analyst, Environmental Resources Management, Palm Beach County, FL; Florida Cooperative Extension Service, Institute of Food and Agricultural Sciences, University of Florida, Gainesville, FL 32611.

The Institute of Food and Agricultural Sciences (IFAS) is an Equal Opportunity Institution authorized to provide research, educational information and other services only to individuals and institutions that function with non-discrimination with respect to race, creed, color, religion, age, disability, sex, sexual orientation, marital status, national origin, political opinions or affiliations. U.S. Department of Agriculture, Cooperative Extension Service, University of Florida, IFAS, Florida A. \& M. University Cooperative Extension Program, and Boards of County Commissioners Cooperating. Larry Arrington, Dean 
resources, practices may be cost-shared up to $90 \%$ of the value. The program may provide incentive payments to encourage farmers to adopt beneficial land management practices such as nutrient and irrigation management, manure management, wildlife habitat management, or integrated pest management. These incentive payments can be collected for up to 3 years (USDA-NRCS, 2004).

In the 2008 Farm Bill, the EQIP funding has been increased by over $\$ 3$ billion. The new Farm Bill also established the Agricultural Water Enhancement Program to help producers address water quality and quantity concerns (U.S. House Committee on Agriculture, 2008).

The EQIP's national and state priorities are:

- Reduce pollutants such as excess nutrients, pesticides, and salinity that may harm surrounding surface or ground water resources.

- Reduce emissions such as oxides of nitrogen, organic compounds, and particulate matter to protect air quality.

- Reduce soil erosion and excess sediment accumulation on farm land.

- Protect existing habitats of endangered and threatened wildlife (NRCS; 10/2004).

To be eligible for EQIP funds, the applicant must be an agricultural producer who will develop a plan of operation that includes specific environmental conservation measures to be achieved, identifies one or more conservation management practices that will be used, and includes an implementation timeline. Application deadlines for this program are determined annually by the NRCS. The deadlines for applications are typically posted to the following web site

http://www.fl.nrcs.usda.gov/programs/eqip/eqip2008/ fleqip2008.html (USDA-NRCS, 2008).

\section{Wetlands Reserve Program (WRP)}

The WRP provides technical and financial assistance to landowners who voluntarily take action to improve and restore wetlands and create wildlife habitat for potential future recreation (NRCS;
9/2004). There are three enrollment options for this plan.

Permanent Easement: This plan offers payment for the agricultural value of the land plus $100 \%$ of wetland restoration costs.

30-Year Easement: This plan offers payment for $75 \%$ of the agricultural value of the land plus $75 \%$ of wetland restoration costs.

Restoration Cost-Share Agreement: This plan does not place an easement on the property. The NRCS will pay up to $75 \%$ of wetland restoration costs. Other local agencies, such as private conservation groups may contribute additional funding. Interested landowners are encouraged to pursue other funding sources. (USDA-NRCS, 2004).

Applications for this program are considered year round. Contact your local USDA NRCS office or visit the USDA's website at http://www.sc.egov.usda.gov (USDA-NRCS, 2004).

The 2008 Farm Bill expands WRP by authorizing $\$ 1.3$ billion to enroll new acreage with the maximum enrollment increased to a little over 3 million acres (U.S. House Committee on Agriculture, 2008).

\section{Grassland Reserve Program (GRP)}

The GRP provides assistance to agricultural producers who voluntarily protect, restore, and enhance grasslands. Administered by the NRCS, the program targets grazing and ranch lands in an effort to slow down conversion of these lands to cropping or urban development uses (USDA-NRCS, 2007). Participants in this program limit the use of their land to sustainable grazing or hay production (USDA-NRCS, 2007). The 2008 Farm Bill expands the GRP to add an additional \$300 million (1.22 million acres) to the program (U.S. House Committee on Agriculture, 2008).

There are several enrollment options:

Permanent Easement: The land owner is paid the fair market value of the land minus the grazing value of the land. 
30-Year Easement: The land owner is paid $30 \%$ of the fair market value of the land minus the grazing value of the land.

Rental Agreement: These agreements can have 10,15 , or 30 years contract lengths and the land owner is paid as much as $75 \%$ of the grazing value of the land for the life of the agreement.

Restoration Agreement: A Grassland Resource Management plan is included within the Easements or Rental Agreements. As much as $90 \%$ of restoration costs may be paid if the land has never been farmed. No more than $75 \%$ of the costs may be paid on previously cultivated land (USDA-NRCS, 2007).

There are several eligibility requirements for this program:

- The landowner must own at least 40 acres that would be included in the program, unless determined by special circumstances.

- The landowner must have a title to their land to be eligible for easement programs or have general control of the acreage to be eligible for the rental agreement.

- Individuals cannot have a gross income of more than $\$ 2.5$ million per year.

Application to this program is accepted the year around. Applications can be found online at http://www.fl.nrcs.usda.gov/programs/flgrp.html (USDA-NRCS, 2007).

\section{Wildlife Habitat Incentives Program (WHIP)}

The WHIP provides financial and technical assistance to landowners who voluntarily improve and or create fish and wildlife habitat (USDA-NRCS, 2004). The NRCS provides counseling on management practices and habitat development for specific species. The land owner retains all ownership of the land, but agrees to refrain from using it for a certain period of time. Federal payment is based on the plan to which both the NRCS and the private land owner agree (USDA-NRCS, 2004). Agreements usually include a period of 5 to 10 years. If a land owner commits to 15 years, cost share rates may be increased (USDA-NRCS, 2004).

Lands that are eligible include: Privately owned land (no acreage requirements), federal land, state and government owned land, and tribal land (NRCS; 9/2004). Applications are received throughout the year and can be found online at: www.sc.egov.usda.gov.

\section{Conservation Security Program (CSP)}

Beginning October 2009, the CSP has been restructured into the new Conservation Stewardship Program as per the 2008 Farm Bill providing over $\$ 1$ billion in funding (U.S. House Committee on Agriculture, 2008), with the same objectives. The current CSP program is designed to reward agricultural producers who have a record of implementing practices that conserve and protect soil water, wildlife habitats, air, and environmentally responsible energy production. The CSP is open to agricultural producers who meet at least one of the following levels of conservation (USDA-NRCS, 2007):

Level 1: The farmer addresses the environmental soil and water quality issues on a portion of their land.

Level 2: The farmer addresses the environmental soil and water quality issues for the entire agricultural operation.

Level 3: The farmer addresses an additional resource concern other than soil and water on their entire operation by the end of the contract duration (NRCS;4/2007).

The funding provided depends on the following:

- An annual stewardship payment contribution for the level of conservation treatment.

- A maintenance payment for maintaining existing conservation practices. 
- An enhancement payment for conservation practices that go beyond the contracted agreement.

- A one time cost-share payment for additional conservation practice implemented (USDA-NRCS,2007).

The amount of funding is negotiated in a contract between the NRCS and the farmer. Each year the NRCS will issue a sign-up notice. Applicants are approved based on the amount of funding available and the priority watershed for that year as determined by NRCS (USDA-NRCS, 2007).

\section{References}

1. U.S. House Committee on Agriculture. 2008. 2008 Farm Bill Conservation Title: Investing in Conservation Programs that Preserve Natural Resources.

http://agriculture.house.gov/inside/FarmBill.html

2. USDA-NRCS. 2002. Summary of NRCS Conservation Programs. Natural Resource Conservation Society, USDA. Accessed on 10/23/08 http://www.nrcs.usda.gov/programs/farmbill/ 2002/pdf/ProgSum.pdf

3. USDA-NRCS. 2004. "Environmental Quality Incentives Program". Natural Resource Conservation Society, USDA. Accessed on 10/23/08 http://www.nrcs.usda.gov/programs/farmbill/ 2002/pdf/EQIPFct.pdf

4. USDA-NRCS. 2004. Wetland Reserve Program. Natural Resource Conservation Society, USDA. Accessed on 10/23/08 http://www.nrcs.usda.gov/programs/farmbill/ 2002/pdf/WRPFct.pdf

5. USDA-NRCS. 2006. Grassland Reserve Program. National Resource Conservation Society, USDA. Accessed on 10/23/08 http://www.nrcs.usda.gov/programs/GRP/ pdf_files/GRPFactSheet3-6-06.pdf and http://www.nrcs.usda.gov/programs/GRP/
6. USDA-NRCS. 2004. Wildlife Habitat Incentives Program. Natural Resource Conservation Society, USDA. Accessed on Oct 23, 2008 http://www.nrcs.usda.gov/programs/farmbill/ 2002/pdf/WHIPFct.pdf and http://www.nrcs.usda.gov/programs/whip/

7. USDA-NRCS. 2008. Conservation Security Program. Natural Resource Conservation Society, USDA. Accessed on 6/23/08 http://www.nrcs.usda.gov/programs/csp/ pdf_files/csp_fs3_05.pdf

8. USDA-NRCS. 2008. Florida 2008 State EQIP Sign-Up and Application Information". Natural Resource Conservation Society, USDA.

Accessed on 6/23/08, 2008 http://www.fl.nrcs.usda.gov/programs/eqip/ eqip2008/fleqip2008.html 